\title{
Effect of microbial fertilizers and dosage of NPK on growth and yield of Upland Rice (Oryza sativa
}

L.)

\author{
Betty Natalie Fitriatin ${ }^{1}$, Robi Silpanus ${ }^{2}$, Emma Trinurani Sofyan ${ }^{1}$, Anni \\ Yuniarti ${ }^{1}$ and Tien Turmuktini ${ }^{2}$
}

${ }^{1}$ Soil Science Department, Agriculture Faculty ofUniversitasPadjadjaran, Indonesia

${ }^{2}$ Agriculture Faculty of Winay amukti University, Indonesia

\begin{abstract}
Microbial fertilizers are inoculants made from beneficial microbes to improve soil nutrient availability and increase plant growth.The purpose of this research was to studythe effect of inoculants as microbial fertilizers (phosphate solubilizing microbes and Nitrogen-fixing bacteria) and NPK fertilizers on growth and yield of upland rice on Andisols. This experiment used a Randomized Block Design (RBD) in factorial pattern, consisting of two factors with three replications. The first factor consisted of inoculants, which were; without; inoculants A (Pseudomonas mallei, P. cepaceae, Aspergillusniger and Penicillium sp., Azotobacter sp., Azospirillum sp.); inoculantsB (Azotobacterchoroococum, A. viilandii, Azospirillum, Pseudomonas cepaceae, Penicillium and Acitenobacter) and inoculants $A+B$. The second factor were NPK fertilizers with four levels (100\%, 75\%, 50\% and 25\% dosage of recommendation). The results showed that microbial fertilizers improve growth and yield of upland rice.
\end{abstract}

Keywords-inoculants, microbial fertilizers, upland rice.

\section{INTRODUCTION}

The increased of rice productivity is still constrained, such as the problem of land conversion which is still occur a lot nowadays, climate factors and also a decrease in the quality of land resources (soil sickness) that can affect the decline or slope of productivity (Karmakar, et al. 2016). Farmers usually use inorganic fertilizersto increase land productivity. The tendency of more intensive use of inorganic fertilizers causes a decrease in the content of soil organic matter and the ability of soil to store and release nutrients and water for plants (Issaka, et al. 2019). As a result, the efficiency of the use of fertilizers and irrigation water as well as land productivity have been moredeclined, resulting in negative impacts on environmental and aquatic sustainability.

$\mathrm{N}, \mathrm{P}, \mathrm{K}$ fertilizers are very good fertilizers for growth and production of crop products. The use of appropriate fertilizers is one of the main factors that influence plant growth. The use of different dosageof fertilizers can have different effects. Fertilizers, in addition to increasing production and quality of harvests, can also increase plant resistance to the disturbances of pests, diseases and drought.

Many efforts have been made to increase rice productivity in dry land, one of which is fertilizing the soil in the form of artificial fertilizers or natural fertilizers, but many obstacles are encountered with this artificial fertilization. One of them is the residual effect of fertilizers that can pollute the environment, so that continuous fertilization will causean adverse effect on the physical, chemical and biological properties of the soil. This chemical fertilizer residue also adversely affects the soil.

Efforts to restore and increase land productivity in a sustainable manner can be done by utilizing biological resources, and $\mathrm{N}, \mathrm{P}, \mathrm{K}$, fertilizers.Microbial fertilizers are inoculants made from active living organisms in liquid or solid forms that have the ability to mobilize, facilitate and increase unavailable soil nutrient availability to become available form through biological processes.

Groups of potential microbial fertilizers to be applied to integrated and sustainable farming systems include: $\mathrm{N}$-fixing, $\mathrm{P}$ and $\mathrm{K}$ solubizingmicrobial, phytohormone-producing soil microbes (plant growth 
promoting rhizobacteria) (Noumavo, et al., 2013) decomposers and microbes acting as biological agents (Singh and Purohit 2011). Microbial fertilizersthatplay the mostrole in increasing nutrient status of sub-optimal soils include phosphate solibulizingmicroorganisms and Nitrogen-fixing bacteria. Based on the description above, it is necessary to do research on the effect of microbial fertilizers and N.P.K dosage on growth and yield of upland rice (Oryza sativa $\mathrm{L}$ ).

\section{METHODS AND MATERIALS}

The pot experiment was conductedin the experimental garden of the Faculty of Agriculture, WinayaMuktiSumedang University, with the altitude of 856 $\mathrm{m}$ above sea level in May-October 2018, using a $15 \mathrm{~kg}$ soil polybag.

The experimental design useda Randomized Block Design (RBD) in factorial pattern, consisting of two factors with three replications. The first factor was the inoculant of microbial fertilizers which consisted of four levels: without the inoculant of microbial fertilizers; inoculant A (Pseudomonas mallei, P.cepaceae, A.niger, Penicilliumsp, Azotobacterchroococum, Azospirilumsp.); inoculant B (P. cepaceae, Azotobacerchroococum, A. vilandii, Azospirilum, Penicillium, Acitenobacater); mixture of $\mathrm{A}+\mathrm{B}$ inoculants. The second factor was the dosage of $\mathrm{N}, \mathrm{P}, \mathrm{K}$ which consisted of four levels, namely: $100 \%, 75 \%, 50 \%$, and $25 \%$ dosage of recommendations. The dosage of microbial fertilizers is $50 \mathrm{~kg} \mathrm{ha}^{-1}$ while the recommended dosage of NPK fertilizer was Urea $250 \mathrm{~kg} \mathrm{ha}{ }^{-1}$, SP-36 $100 \mathrm{~kg} \mathrm{ha}^{-1}$, $\mathrm{KCl} 100 \mathrm{~kg} \mathrm{ha}{ }^{-1}$. The soil used as a planting medium
wasAndisols from Tanjung Sari which have the characteristics: soil $\mathrm{pH}$ 6.1; Organic C (2.90\%); N-total (0.23\%) $\mathrm{C} / \mathrm{N}$ (13) $\mathrm{P}_{2} \mathrm{O}_{5}$ (96.58 mg $100 \mathrm{~g}^{-1}$ ); available P Bray 1 (15.00 mg $\left.100 \mathrm{~g}^{-1}\right) ; \mathrm{K}_{2} \mathrm{O}$ (15.21 mg $100 \mathrm{~g}^{-1}$ ), CEC (24.43 $\left.\mathrm{cmol} \mathrm{g}^{-1}\right)$. Upland rice seeds using Situ Bagendit varieties. Observations on plant growth consisted of plant height and number of tillers whichwere being observed periodically until the end of vegetative phase.

Propagation of isolates of phosphate solubilizing microbes and Nitrogen-fixing bacteria using nutrient broth (NB) while phosphate solubilizing fungi using potato dextrose broth (PDB). Each pure culture of each is olate was inserted into the multiplication medium as much as $10 \%$ of the volume of the media then shaken with a $112 \mathrm{rpm}$ shaker for 3 days.

The population of phosphate solubilizing bacteria,phosphate solubilizing fungi and Nitrogen-fixing bacteria were calculated using the Total Plate Count method before being added to the carrier material, which were peat mixture and compost in the ratio of 1: 1 as much as $10 \%$ byweight of the carrier material.

\section{RESULTS AND DISCUSSION}

\section{Shootroot ratio}

Shoot root ratio (SRR) shows the spread of photosynthate. The ratio of photosinthatebigger than 1 indicates that photosynthate in the sprout or shoot is higher than being stored in the root. This shows good vegetative growth since many photosinthates are contained at the top (shoot).

Table.1: Shoot root ratio at the end of vegetative phase

\begin{tabular}{ll}
\hline Treatments & $\begin{array}{r}\text { Shoot root ratio } \\
(\text { SRR) }\end{array}$ \\
\hline Microbial fertilizers & $2,91 \mathrm{a}$ \\
- control & $2,04 \mathrm{a}$ \\
- Inoculants A & $2,58 \mathrm{a}$ \\
- Inoculants B & $1,44 \mathrm{a}$ \\
- Inoculants A+B & \\
\hline N,P,K fertilizers & $2,12 \mathrm{a}$ \\
$-100 \%$ & $2,91 \mathrm{a}$ \\
$-75 \%$ & $1,61 \mathrm{a}$ \\
$-50 \%$ & $2,32 \mathrm{a}$ \\
$-25 \%$ &
\end{tabular}

Note : The average value followed by the same letter is not significantly different according to Duncan's Multiple Range Test at the level of $5 \%$. 
The experimental results showed that the application of microbial fertilizers and NPK did not significantly affect the shoot root ratio. However, the application of microbial fertilizers tends to reduce the value of SRR. It is suspected that the presence of microbial fertilizers stimulates root growth so that root growth becomes more abundant. Rapid root growth can be caused by IAA hormones produced by microbes in microbial fertilizers. Research result of Dhungana and Itoh (2019) showed that Inoculation with Klebsiella sp. the highest IAA producer among the test strains, increased fresh root weight of tomato and radish. This is supported by the research results of Fitriatin et al. (2014), that phosphate solubilizing bacteria are able to produce plant growth regulators which is capable of spurring corn growth.

\section{Components of Upland Rice Yield}

Observation of yield components was conducted on productive tillers, panicle length, dry grain harvestweight and one hundred grain weight at harvest time (end of generative phase). The results of the experimentshowed that in general the application of microbial fertilizers consortium significantly increased the yield of upland rice.

The result of the experimentshowed that the application of inoculantof microbial fertilizers significantly increases the number of productive tillers. This is in line with the research results ofBiswakarma et al. (2018) who reported that the application of phosphate solubilizing microbes was able to increase the number of rice tillers.
Based on the results of this experiment, it was shown that inoculant A (Pseudomonas mallei, P. cepaceae, A.niger, Penicilliumsp, Azotobacerchroococum, Azospirilumsp.) was better in increasing the number of tillers than inoculant B (P. cepaceae, Azotobacerchroococum, A. vilandii , Azospirilum, Penicillium, Acitenobacater) or even a mixture of inoculants $\mathrm{A}$ and $\mathrm{B}$.

The effect of reducing the dosage of N,P,K fertilizer from $100 \%$ to $25 \%$ has a significant effect on the number of tillers. This shows that the application of inoculants of microbial fertilizers is able to increase the efficiency of inorganic fertilizers that is in the absence of an effect of a marked decrease in plant growth (number of tillers) due to a reduction in N,P,K dosage.Naher et al. (2016) reported that application of biofertilizer reduce $50 \%$ chemical fertilizer and increase yield of rice.

Inoculant of microbial fertilizers A which complies with the microbes of Pseudomonas mallei, P. cepaceae, A.niger, Penicilliumsp, Azotobacerchroococum, Azospirilum sp. give a better influence in increasing crop yields, namely dry grain harvest up to $32.08 \%$ and a weight of 1000 grains increased up to $10.58 \%$ compared to without microbial fertilizers.Research results of Salamone et al. (2012) indicate that inoculation of paddy rice with Azospirillumbrasilense and Pseudomonas flurescensincrease crop production.

Table 2. Effect of microbial fertilizers and NPK on upland rice yields

\begin{tabular}{lcccc}
\hline Treatment & $\begin{array}{l}\text { Productive } \\
\text { tillers }\end{array}$ & $\begin{array}{l}\text { Panicle } \\
\text { length }(\mathrm{cm})\end{array}$ & $\begin{array}{l}\text { Weight } \\
\text { GKP(g/pot) }\end{array}$ & $\begin{array}{l}\text { weight } \\
\text { grains }(\mathrm{g})\end{array}$ \\
\hline Microbial fertilizers & & & & \\
- without inoculant & $32,89 \mathrm{a}$ & $1,77 \mathrm{a}$ & $39,00 \mathrm{a}$ & $21,56 \mathrm{a}$ \\
- Inoculant A & $37,45 \mathrm{~b}$ & $2,09 \mathrm{~b}$ & $51,51 \mathrm{~b}$ & $23,84 \mathrm{~b}$ \\
- inoculant B & $34,54 \mathrm{ab}$ & $2,02 \mathrm{~b}$ & $40,01 \mathrm{a}$ & $22,15 \mathrm{a}$ \\
- inoculant A+B & $36,16 \mathrm{~b}$ & $2,14 \mathrm{~b}$ & $38,48 \mathrm{a}$ & $21,68 \mathrm{a}$ \\
& & & & \\
\hline N,P,K fertilizers & & & & \\
- 100\% & $37,17 \mathrm{~b}$ & $2,15 \mathrm{~b}$ & $45,38 \mathrm{a}$ & $21,97 \mathrm{a}$ \\
- 75\% & $36,25 \mathrm{ab}$ & $2,00 \mathrm{a}$ & $41,01 \mathrm{a}$ & $22,50 \mathrm{a}$ \\
- 50\% & $34,70 \mathrm{a}$ & $1,92 \mathrm{a}$ & $44,40 \mathrm{a}$ & $22,33 \mathrm{a}$ \\
- 25\% & $32,93 \mathrm{a}$ & $1,95 \mathrm{a}$ & $38,22 \mathrm{a}$ & $22,42 \mathrm{a}$
\end{tabular}

Note: The average value followed by the same letter is not significantly different according to Duncan's Multiple Range Test at the level of $5 \%$. 


\section{CONCLUSIONS}

The application of microbial fertilizersinoculants A (Pseudomonas mallei, P.cepaceae, Aspergillusniger, Penicillium sp. Azotobacerchroococum, Azospirilum sp.) and inoculants B (Pseudomonas cepaceae, Azotobacerchroococum, Azotobactervilandii, Azospirilum, Penicillium, Acitenobacater) and the mixture between the two can increase the growth and yield of upland rice plants. Inoculant A was able to provide a better influence on the growth and yield of upland rice.

Reducing the dosage of N, P, K fertilizer to $25 \%$ accompanied by the application of microbial fertilizers can provide results that are not significantly different from the provision of $100 \%$.Therefore, giving microbial fertilizers can reduce the need for NPK fertilizer on upland rice plants.

\section{ACKNOWLEDGEMENTS}

This research was supported by grants received (applied research :16/UN6.E/LT/2018) from the Directorate General of Higher Education Ministry of Research and Technology Indonesia. We thank tostaff Laboratory of Soil Biology and Laboratory of Soil Fertility and Plant Nutrition Faculty of Agriculture, Universitas Padjadjaran for their cooperation. We are also thankful to our students Fahmi and Yusuf for supporting us during experiment at field.

\section{REFERENCES}

[1] Biswakarma, B., H. Verma and N.C. Sarkar. 2018. Effect of phosphate solubilizing bacteria on yield of transplanted rice under lateritic belt of West Bengal, India. International Journal of Current Microbiology and Applied Sciences 7(2): 3192-3204

[2] Dhungana, S.A. and K. Itoh. 2019. Effects of co-inoculation of indole-3-aceticacid-producing and -degrading bacterial endophyteson plant growth. Horticulturae: 5 (17); 1-9

[3] Fitriatin, B.N. , A. Yuniarti, and T.Turmuktini. 2014.The effect of phosphate solubilizing microbe producing growth regulators on soil phosphate, growth and yield of maize and fertilizer efficiency on Ultisol. Eurasian Journal of Soil Science.(3): $104-107$.

[4] Issaka F., Z. Zhang, Z. Zhao, E. Asenso, JH. Li, YT. Li, and JJ. Wang. 2019. Sustainable conservation tillage improves soil nutrients and reduces nitrogen and phosphorous losses in maize farmland in Southern China. Sustainability.(11): 2397; 1-13

[5] Karmakar,R., I. Das, D.Dutta and A.Rakshit. 2016.Potential effects of climate change on soil properties: A Review. Science International.Volume 4 (2): 51-73

[6] Naher,U.A., Q.A.Panhwar, R. Othman, M.R. Ismail andZ. Berahim. 2016. Biofertilizer as a supplement of chemical fertilizer for yieldmaximization of rice. Journal of Agriculture Food and Development.(2):16-22

[7] Noumavo, P.A., E.Kochoni, Y.O. Didagbé, A.Adjanohoun, M. Allagbé, R. Sikirou, E.W. Gachomo,S.O. Kotchoni, and L. Baba-Moussa. 2013. Effect of different plant growth promoting rhizobacteria on maize seed germination and seedling development. American Journal of Plant Sciences. (4): 1013-1021

[8] Salamone, I. E.G.D., J.M. Funes, L.P.D. Salvo, J.S.E. Ortega, F. D'auria, L. Ferrando and A.F. Scavino. 2012. Inoculation of Paddy Rice with Azospirillumbrasilenseand Pseudomonas flurescens: Impact of plant genotypes on rhizosphere microbial communities and field crop production. Applied Soil Ecology 196-204.

[9] Singh, T and S.S. Purohit. 2011. Biofertilizers Technology. Agrobios (India). ISBN. 13:978-81-7754-382-7. 